\title{
Control Modes in the Age of Transnational Governance
}

\author{
DIRK LEHMKUHL
}

\begin{abstract}
The article starts with the observation that there are overlaps in, so far, largely unrelated research programs concerned with the legalization in international relations, on the one hand, and transnational regulation and governance, on the other. The analysis of the literature at the interface between the "fourth strata of the geology of international law" and the "governance in the age of regulation" literatures reveals a substantial common interest in structures of transnational regulatory governance. At the same time, the theoretical toolkit of both strands of literature does not match the task of coping analytically with structures and processes in the overlapping realm. To sharpen the analytical edge, the article elaborates hierarchy, market, community, and design as four ideal types of control modes in transnational regulatory spaces. The application of this model to the empirical analysis of a number of regimes underpins the observation that control frequently occurs in hybrid regulatory constellations involving public and private actors across national and international levels. A key example concerns the prominence of domestic regulatory regimes in underpinning transnational governance processes, where national rules achieve extraterritorial effect as much through competitive as through hierarchical mechanisms.
\end{abstract}

\section{INTRODUCTION ${ }^{1}$}

The starting point of the article is the observation that there are significant overlaps in, so far, largely unrelated strands of literature, the debate on the legalization of world politics, on the one hand, and the booming literature on governance in the age of regulation, on the other. The former addresses the expansion of rule-based relations and judicial management in international affairs; the latter has discovered the spread of Anglo-Saxon style regulatory governance of markets into transnational spaces (see for the former for instance Goldstein et al. 2001; Shapiro and Stone Sweet 2002; for the latter

The author is grateful to four anonymous reviewers and the editors of Law \& Policy for their intriguing comments.

Address correspondence to: Dirk Lehmkuhl, University of St. Gallen, Chair of European Politics, Bodanstrasse 8, 9000 St.Gallen, Switzerland. Telephone: +41- (0) 71224 3985; E-mail: dirk.lehmkuhl@unisg.ch. 
Braithwaite and Drahos 2000; Diehl, $\mathrm{Ku}$ and Zamora 2003; Levi-Faur 2005; Levi-Faur and Jordana 2005; Reus-Smit 2004b; Scott 2004; Zangl and Zürn 2004). While the former is rooted in international relations theories on international cooperation and regime theory, the latter involves scholars with a domestic and comparative public policy background. The two strands meet in the observation that governance, defined as the processes through which rules evolve, develop and are implemented, is no longer a privilege of states and governments. Rather, the emerging common sense is that the essence of transnational ${ }^{2}$ regulatory governance is its focus on a broader range of governing mechanisms which do not necessarily rest on recourse to the authority and sanction of government (Stoker 1998: 17).

However, the converging interest in issues of transnational regulatory governance poses specific problems for both sets of literature. On the one hand, conventional state-centric approaches according to which international law and international institutions regulate interactions between states are challenged by the dispersal of capacities and resources relevant to the exercise of power among a wide range of actors and organizations including states, international organizations, and nonstate actors (for instance Bruce Hall and Biersteker 2002; Cutler, Haufler and Porter 1999; Haas 1992; Rosenau 1992; Strange 1996). On the other hand, the literature on the global diffusion of regulatory governance is dominantly concerned with the history, causes, and patterns of diffusion of new regulatory policies such as privatization, delegation, and the growth in the influence of experts (Jordana and Levi-Faur 2004). Its focus on policies and instruments is frequently comparative and cross-national, while the transnational dimension has only recently gained more prominence (Djelic and Sahlin-Andersson 2006), and the awareness of differential empowerment of states still remains a blind spot on the conceptual map.

As a consequence, it is possible to identify the convergence with respect to the issues under study, while there is still some mileage to be gained in the analytical dimension. For instance, the interest in the international diffusion of policies might benefit from the insight of international relations that power differentials between states continue to play a role when it comes to the decision about governance structure in sectoral regimes (Drezner 2004). At the same time, the socio-legal literature on regulation provides a rich body of work on nonlegal forms of regulation that may help to qualify the strong emphasis on state-made law and that provide clues for alternative approaches (Gunningham and Grabosky 1998; Hood 1983, 2007; Morgan and Yeung 2007; Parker et al. 2004).

However, before elaborating on an alternative, I will address the convergence of two literatures of international relations, on the one hand, and regulatory governance, on the other, in more detail. Special attention will be given to the potential and limits of law in the coordination of behavior in internationalized environments (section II). Section III intensifies the discussion on law and other modes of coordination. Rather than focusing on the 
entire policy cycle, the debate concentrates on modes of control as the way in which rules and regulation actually work. The focused discussion allows for identifying four ideal-typed modes: hierarchy, market, community, and design. Section IV picks up the typology and puts some empirical flesh to the analytical bones. What will be shown is that implementation and enforcement frequently occur in hybrid regulatory constellations involving public and private actors across national and international levels.

\section{LEGALIZATION AND THE AGE OF TRANSNATIONAL REGULATION}

\section{A. THE TRADITIONAL PICTURE IN INTERNATIONAL RELATIONS}

A move to law or law-like arrangements seems to be a longer-term trend in international affairs since the second half of the twentieth century. Affecting more and more issue-areas, this move to law finds expression in an increase in the number of international contracts, a shift toward legally binding treaties and a delegation of conflict resolution to international tribunals. The quantitative and qualitative changes in the relation between states, labeled as legalization or judicialization of world politics (Goldstein et al. 2001; Shapiro and Stone Sweet 2002), have been addressed differently by theoretical accounts of international relations.

The basic tenet of the two dominant theoretical approaches that for a long time dominated the theoretical reflections about international politics, that is, neorealism and liberal institutionalism, is the construct of a Westphalian state model that is equipped with the domestic and external sovereignty (Krasner 1999). According to this construct, the idea of centralized and hierarchic domestic systems represents the antipode to the decentralized and anarchic character of the international political systems, with anarchy describing the absence of an overarching authority (Waltz 1979). The mainstream of these approaches follows an instrumentalist optic according to which international law provides a means for states to attain their interest in relation to other states (Keohane 1997: 488). According to power- and interest-based approaches to international law, utilitarian calculations may contribute to a state's willingness to participate in international rule making and comply with international rules because international law either preserves the advantages of the powerful or it saves transactions costs. The standard interpretation of institutional regime theory is that states opt for more legalized or institutionalized forms of cooperation as long as they provide superior net benefits when compared to less institutionalized or legalized arrangements (Kahler 2001: 278-88). Hence, the degree of legalization varies according to cost-benefit calculations of states in their efforts to solve commitment problems related to international cooperation. Given the absences of a superior authority, reference to rational acting states serves also to explain defection and other compliance-related problems (Abbott and Snidal 2001). 
In stark contrast, constructivist approaches to world politics refer to the part of the classical definition of a regime ("principles, rules and norms that may function as nodes 'around which actors' expectations converge" (Krasner 1983: 2)) that emphasizes the cognitive dimension of regime emergence and operation. Constructivists doubt realists' assumptions that legalized agreements can be understood through purely instrumental lenses (Kratochwil 1989: 198). Rather, central to their approach is "that outcomes in the international arena... are moulded by norms and common understandings which represent some form of governance" (Kratochwil 2000: 53). Rules and norms frame and channel interests as actors learn to internalize new rules and norms through processes of persuasion and social learning and, in turn, redefine their interests and identities accordingly in order to become members of international society "in good standing" (e.g., Finnemore and Sikkink 2001; Reus-Smit 2004a). Rather than rational calculations, internalization of norms and their legitimacy become important preconditions for compliance (Checkel 1999; Neyer and Zürn 2001).

There are, however, more and more efforts to integrate the analytical potential of different approaches (Hasenclever, Mayer and Rittberger 2000; Risse 2002). There is, for instance, the observation that "law both reflects (and shapes) the values and serves (and shapes) the interests of those it governs" (Abbott and Snidal 2002: 142). Thus, the interaction between interests and values drives the legalization in a particular field "both in particular episodes and through deeper interrelationship over time" (ibid.: 141). At the same time, alongside the acknowledgment that cooperation rather than conflict has become a dominant feature in international affairs, international relations theorizing has started to incorporate into their analyses actors other than states, including substate units and international organizations.

An important contribution to this continuously growing body of literature is Slaughter's new world order. With her concept of disaggregated states, Slaughter describes order in international affairs based on the cooperation of functional-equivalent units of national administrations in transnational networks and the respective transnational legal mechanisms enacted by these transnational networks (Slaughter 2004). What Slaughter basically does is to give a name to the increasing regulatory cooperation that can be found in many issue areas, including financial markets (such as the Basle Committee on Banking Supervision or the International Organization of Securities Commissions), antitrust (see, e.g., The International Competition Network), or food and drug regulation (see the Codex Alimentarius Commission). Weiler aptly coined these forms of cooperation as a "fourth strata' in the geology of international law." ${ }^{33}$ Characteristic for the fourth strata is the existence of more or less formalized regulatory regimes and governance structures rather than treaties or formal international organizations.

Despite their merits, the approaches aptly mirror the problems of international relations and international law as disciplines to come to grips with the role of nonstate actors. Basically, the pluralization of international 
affairs in terms of an increase of actors and locations contributing to influence the behavior of both states and private actors is acknowledged-but still states or substate units are the relevant actors. In analytical terms, it still requires an additional step from acknowledging that nonstate actors have become powerful players in international affairs to accepting that private regimes or rules-systems may operate without the state.

This additional next step has been taken in recent important contributions that analyze how informal and voluntary standards increasingly complement international lawmaking by states (Kirton and Trebilkock 2004). In a similar vein, attention is given to the rich picture of law-like arrangements in international politics in terms of a growth (an increase in breadth and depth of arrangements), a variation (a double transformation of international law, its principles and objects), and a differentiation (pluralization, privatization, and hybridization of arrangements) (Brütsch and Lehmkuhl 2007). Both volumes move away from narrow concerns of what is law and what is not and, rather, pay attention to the regulatory properties law or law-like arrangements.

\section{B. THE CONVERGENCE OF TWO DEBATES}

At this point, we are at the center of the overlap between the debates on legalization in international relations and on the diffusion and internationalization of regulatory governance. The overlaps results from a convergence of two so far largely unrelated realms of analysis. To start with, the debate on the move to law in international relations has spread beyond the traditional realms of research in international relations such as (non)cooperation and defection of states in realms such as war and peace, trade, or human rights. Also, the interest is no longer basically in why regimes are built or not, but in their functioning and effects. Research questions relate more and more to the operational dimension of international organizations and regimes, and studies also developed an interest in international administrative law, including policy areas such as environment, transport, or telecommunication (Young 1994; Zacher and Sutton 1996).

By so doing, it comes ever closer to literature on regulatory governance. On their part, authors in this strand have discovered the spread of Anglo-Saxon style regulatory governance into transnational spaces (Braithwaite and Drahos 2000; Djelic and Sahlin-Andersson 2006; Ronit and Schneider 2000). In this realm, so they discover, there exists already an institutional web of international organizations and international norms that seek to maintain and expand influence in the governance arrangements beyond the level of the nation state. With their emphasis on a variety of regulatory instruments and the self-regulatory capacity of epistemic and professional communities within issue areas and (sub)sectors (Jordana 2005: 185), the literature on globalizing regulatory capitalism and transnational governance in the making ties up to the more recent debate in the legalization literature that draws a multifaceted picture of the transnational move to law, including "legalisation 
from the periphery" (Teubner 2001), that is, the norm-setting and implementing capacity of nonstate actors.

In other words, addressing these two strands of analysis, we are at the interface between the transnational relations and private authority literature, on the one hand, and the literature on global governance and the new regulatory (world) order, on the other. While the former builds on the plurality of governance "by, with and without" government" (Rosenau 1992; Young 1997; Zürn 1998), the latter draws a picture of a patchwork of political structure across regions and borders with a variety of regulatory instruments in any given policy area (Levi-Faur 2005). While the former has its origin in the debate on international interdependence and transnationalism of the 1970s and has been revived since the mid 1990s (e.g., Kaiser 1969; Keohane and Nye 1971a, 1971b; Mansbach, Ferguson and Lampert 1976; Risse-Kappen 1995), the latter has emerged from the domestic and comparative studies literature with its observation that governance through regulation has ceased to be an American peculiarity (Jordana and Levi-Faur 2004; Majone 1996).

The irony in the observation that the institutional advance of policies inspired by neo-classical economic theories, including privatization, deregulation, and liberalization has contributed to more rather than less regulation at the domestic level is not our topic here. Rather, we are interested in the ascent of the "golden era of regulation" (Levi-Faur and Jordana 2005), which can to a large extent be explained by the fact that markets cannot do without rules to be stable (Fligstein 2001). This holds both for market-making rules and for market-correcting rules. Thus, what characterizes the new regulatory order are regulations for the market and regulations in the market. In analytical terms, this implies that the new regulatory order has interrelated economic, political, and social dimensions. The linkages between the three dimensions of regulatory capitalism can be described in the following way:

The state is embedded in the economic and social order; any change in the state is expected to be reflected in the economy and the society, and vice versa. That much is reflected through the various dimensions of regulation. Thus, efficient markets do not exist outside the state and the society in which they operate, and efficient markets may require not only strong regulatory frameworks but also efficient ones. [...] At the same time, the legitimacy of capitalism rest on the ability of government to mitigate negative externalities through "social regulation" (or the regulation of risk). Regulation is both a constitutive element of capitalism (as the framework that enables markets) and the tool that moderates and socializes it (the regulation of risk). (Levi-Faur 2005: 14)

Yet, moving from the domestic to the international realm, the relationship between state, economy, and society poses substantial problems for the question of the regulations of markets. On the one hand, the shift to neoliberal international policies has not only contributed to an expansion of international markets for goods, services, and capital, but it has cast doubts on the capacity of public actors including states, international regimes, and 
international organizations to fetter free markets. On the other hand, the societal constituency in an internationalized environment is somewhat amorphous. While in the national realm it was clearer which interests had to be compensated to embed liberalism, at the international realm (civil) society has little contours.

Given these problems, the potential of societal contributions to influence, structure, and control human and social activities has gained much attention. While states are still territorially restricted and international cooperation has its well-known limits of being slow and frequently loaded with opposing interests, private actors have the potential to transcend national and cultural boundaries. Just to mention a few examples, one might start by referring to the role of bond rating agencies that are much more than information broker in financial markets but also transmit a specific economic and organization mode (Sinclair 2005). A quite different example is the Global Compact promoted by the United Nations as a trilateral effort of companies, nongovernmental organizations and the United Nations to push social and environmental goals (Zammit 2003). A third example refers to the emergence of private certification of sustainable timber products. Given the failure of international cooperation between states on this issue, on the one hand, and the incompatibility of national legislation on tropical timber imports with international free trade provisions rules of the Generalized Agreement on Tariffs and Trade, it was the Forest Stewardship Council that has been established as a private certification initiative to honor sustainable forest management (Bartley 2003; Bernstein and Cashore 2004). These cases are but some examples of the variety of approaches to establish rules for liberalized international markets, involving a variety of actors in different constellations, coming in quite different forms, and, most importantly for the present interest, neither emerge from nor rely on conventional forms of public lawmaking. ${ }^{4}$

\section{REGULATORY STRUCTURES AND CONTROL MODES}

\section{A. ON REGULATORY STRUCTURES RATHER THAN INSTRUMENTS AND CHOICE}

To accept the regulatory capacity of rules other than law is a precondition to engage in broader discussion involving different scholarly background. This discussion requires broadening the conceptual understanding of regulation beyond a narrow interpretation of techniques or instruments that seek to shape the behavior of actors in internationalized environments. But traditional international relations approaches to international law have some problems to engage in such a discussion. Laws in the form of treaties are the means to overcome the imponderability of international politics and its anarchy marked by the absence of an overarching authority, and Article 38 of the International Court of Justice's statute (International Court of 
Justice) enlists the legitimate sources of law, at least for intrastate disputes. As the debates about the legal character of nonbinding international provisions show, however, deviances from the concept of an Austian model of law pose problems (Abbott and Snidal 2001; Shelton 2000, 2008). And yet, in transnational spaces there is a formidable variety of forms that seek to direct behavior in certain ways. As a consequence, any effort to address the features that govern transnational regulations would fall short if it concentrates only on state-made law, on procedures involving states as central actors, or on the threat of legal sanctions. Neither would it be inadequate to focus only on private regulatory approaches and to ignore the relevance of national or regional regulatory efforts. As a consequence, the challenging task ahead is to combine the conceptual insights of the two literatures in a way that allows for using their respective strengths to overcome their respective weaknesses in the analyses of contemporary transnationalized regulatory spaces.

For the analysis of control modes in internationalized environments, it is intriguing to refer to the important findings of the vast literature on regulation and on administrative law. With an empirical reference to the domestic context, this literature provides ample evidence for regulatory arrangements that operate according to a different logic than law, that there are regulators other than states, and instruments other law. ${ }^{5}$ In a recent reflection on the scholarly progress of this literature Hood came to the conclusion that

No single schema could fully capture the variety of all this work on policy
instruments over the past two decades, but much of it has fallen into three
broad categories. One of them could be loosely called the institutions-as-tools
approach, including forms of organization as policy instruments. Another could
be loosely termed the politics-of-instrumentality approach, which problematizes
the political and cognitive processes that lead to the choice of instruments,
instead of taking those processes as given. And a third strain comprises various
other forms of describing or categorizing government's tools in a generic way.
(Hood 2007: 133, emphasis added)

Although being a rough classification, it is very helpful for two reasons. First, it is useful to show that the largest portion of the regulatory literature falls into the "tools" category (e.g., Grabosky 1995; Gunningham and Grabosky 1998; Hood 1983), while both the "politics" category (e.g., Lascoumes and Le Gales 2007) and the "alternative concept" category (e.g., Harter and Fads 1985; Morgan and Yeung 2007; Murray and Scott 2002; Salaman and Elliott 2002) encompass significantly smaller numbers of contributions. To be sure, neither is this enumeration complete nor can the classification claim to do justice to all respective contributions. For instance, some important contributions address specifically one instrument or technique of regulation, such as enforced self-regulation (Ayres and Braithwaite 1992), smarter (self-) regulatory techniques (Gunningham and Grabosky 1998) or architecture (Kaytal 2002). To classify them basically as tool-related contributions would however underrate their importance for the overall analytical debate. 
Yet, second, the classification is useful, as it displays that the overall concern of this literature with the efficiency of instruments and techniques of public policies. The dominant interest is either in identifying tools and improving their efficiency, in analyzing processes that explain why a certain choice has been made in one case and a different choice in another, or identifying combinations of different instruments. Despite all differences between approaches and their degrees of generalization, their common interest is to improve the efficiency and efficacy of public interventions.

This said, it seems appropriate to describe the underlying philosophy of the regulatory literature as being motivational, actor-centered, and to a certain degree functionalistic. A similar tendency could be traced in the literature on the "rise of the regulatory state" with its transaction costs based interpretation of the emergence of regulatory regimes and the delegation of monitoring and enforcement competences to regulatory agencies. ${ }^{6}$ The functionalist account derives from the understanding of instruments, techniques, and micro-tools as means to resolve public policy problems. They are designed by public actors, that is, the state or substate units that opt for a specific instrument or the mix of instruments to achieve a specific regulatory objective. Just to mention a few examples: it is the state that relies upon the command of law (Daintith 1994), delegation by the state to self-regulatory agencies promises the saving of (transaction) costs (Ogus 1995), or, finally, it is the state that mandates disclosure of information (Ayling and Grabosky 2006; Yeung 2005). In all the cases, the "government," the "state," or "administration" choose regulatory instruments and evaluate their achievements. The definition of regulation "as the necessary exercise of collective power through government" (Levine and Forrence 1990: 168) mirrors this interpretation.

In this respect, socio-legal regulation theory is at the heart of the paradigm of "political steering" (Steuerungstheorie) (Kooiman 1993; 1999). It would, however, be wrong to conceive the governance of transnational regulatory spaces simply in terms of an extension of the established logic of the steering paradigm. As recently spelled out by one of the protagonists of the debate, the

concepts "politische Steuerung" and "governance" refer to different aspects of political reality. "Politische Steuerung" is the hallmark of an actor centered approach to policy-making, while "governance" is the hallmark of an institutionalist approach dealing with regulatory structures combining public and private, hierarchical and network forms of action coordination. (Mayntz 2004: 1)

An example may help to illustrate the decisive difference between the two approaches. In their path-breaking work on responsive regulation, Ayres and Braithwaite maintain a focus on public actors in their choice of instruments. Although they explicitly acknowledge the potential of private contributions to achieve the public good, their concept of enforced self-regulation involves prescriptions for policymakers under which conditions public interventions should safeguard compliance and enforcement with public policy objectives (1992). In this respect, their approach is emblematic for the 
broader literature that adopts a steering perspective and puts emphasis on the state (or substate units) and the role of law. Despite similarities in the terminology, Knill and Lehmkuhl focus on regulatory structures rather than primarily on actors when they identify four different constellations in which public and private governance contribution relate to each other ("interfering regulation, interventionist regulation, private self-regulation and regulated self-regulation"). The decisive difference to the actor-centered approach derives from the analysis that relates to the explanation for different patterns. For Knill and Lehmkuhl, the actual combination of different governance contributions varies along three dimensions: the congruence between the scope of the underlying problem and organizational structures of related actors, the type of public good at stake, and the broader institutional context (2002).

Before I continue to further develop the argument on general patterns of control and ordering in transnational regulatory spaces, it seems helpful to recap the relevant analytical points of the discussion of different literatures. To start with, dominant theoretical approaches of the international relations literature have some problems coping analytically with the governance of transnational regulatory spaces. Without being devaluated per se, these approaches have limits for the analyses of global governance with and without the state. At least some of these conceptual difficulties relate to the dominance of power- or interest-based lenses that basically display an instrumentalist logic of law or legal arrangements. The dominant focus on state actors leaves little space to incorporate independent action of nonstate actors or nonstate regulatory activities. In contrast, attention for nonlegal forms of ordering is an established practice for scholars of regulation. Yet, the focus on either institutional design with respective cross-sectoral and international variance or efficiency concerns in the choice of instruments displays the state-centric heritage of the traditional paradigm of political steering. As the above discussed example has shown, however, it is not only necessary to move away from both the functional-utilitarian and the efficiency-oriented choice perspective, but also to internationalize the approaches to cope analytically with the more complex patterns of ordering in transnational regulatory spaces.

The focus on the transnational regulatory structure implies the analysis of the broader governance arrangement in a specific realm. It involves the identification of relevant governance contributions, their supportive or complementing relationship, and the conditions under which they may generate a certain influence. The structural analysis differs significantly from the tools or design approach. Its interest is primarily analytical and relates to the mapping and explanation of specific patterns in governance structures rather than in the conditions and instrumentation for goal achievement. At the same time, for the objective not only to map but also to explain the pattern of a respective governance arrangement, it is helpful to take into account insights from both strands of the literature that have 
been discussed above. For instance, in analytical terms, there is a difference between economic instrument of competition enforced by a public regulator and market forces as a mechanism ensuring compliance in a regulatory structure. ${ }^{7}$ In a similar way, it may be interesting to see whether power asymmetries among states may radiate into the regulation of transnational spaces. These insights provide intriguing clues for the present interest in general ordering principles in transnational spaces of regulation.

\section{B. IDEAL-TYPED MODES OF CONTROL}

My approach to accomplish this task rests on two pillars. To start with, I limit my attention to patterns of control and enforcement. The focus is on the control of rules and norms because it is important to address the way in which rules and regulations actually work (Black 1997: 5). Put differently, for the achievement of intended goals, control modes (as well as enforcement patterns) are decisive dimensions in regulatory governance. In order to identify patterns of control and enforcement that are both distinctive and generalizable, I elaborate on ideal-typical constellations. Since Max Weber's the identification of ideal-types is a means of ordering a field under study at a high level of generalization (1991). The idea is to forge out a pattern from its time and space specificities, and then to use this stripped-off general pattern to identify peculiarities in empirical cases.

A good starting point for the distinction of ideal types of control and enforcement is Ellickson's taxonomy "of all methods through which individuals control themselves and each other" (1991: 123-32). He distinguishes five modes: a first-party controller, an actor that imposes rules and sanctions on himself, the rules being personal ethics; a second-party controller, basically contractual control; and three third-party controllers, law enforcement of governments ("state hierarchies"), organizations enforcing their organizational rules ("nongovernmental hierarchies"), and norm enforcement via nonhierarchically organized social forces.

Interestingly, Ellickson's taxonomy of third-party control modes with its elements of hierarchy and social norms corresponds partly with the analysis of basic types of social ordering. The constitutive concern of this analysis is the study of how interdependence between societal actors is managed. Interdependence is a pertinent feature in complex societies because "[a]ctors are not fully in control of the activities that can satisfy their interests, but find some of those activities partially or fully under the control of others" (Coleman 1990: 29). As a consequence, the analytical challenge is to identify general patterns in which social ordering results from complex structureprocess relationships and the underlying mechanisms of coordination. The theoretical interest in general mechanisms of societal coordination that are the core of ordering in complex societies has not only stimulated basically theoretical discussions at higher levels of abstraction (e.g., Hedström and Swedberg 1998; Schimank 2003, 2007), but also generated more policy-concerned 
approaches (e.g., Lessig 1999; Murray and Scott 2002) that overlap in some parts while being distinct in others.

Its focus on the control dimension of social ordering make Lessig's approach a good opening of this debate. Lessig elaborated on a typology of four modes of ordering and relates them to specific enforcement mechanisms: law relates to state based punishment; market relates to the device of price signals; social norm relates to community-based enforcement; and, finally, architecture relates to enforcement by basic design principles $(1998,1999)$. With the exception of the last mode, Lessig's typology incorporates the most frequently mentioned modes of ordering. Discussing the different modes in turn, I will not only introduce their distinctive properties, but also refine their interpretation to match the present interest in establishing an ideal-type raster to analyze control modes in transnational regulatory spaces.

First, law plays the most prominent role in Lessig's typology. Rather than being replaced by other means of ordering and control, law in Lessig's reading is vital in a twofold sense. In a direct sense, it sets the legal framework for behavior. In an indirect sense, it may positively or negatively influence the three other means of regulation and their way to regulate individuals (Lessig 1998: 666-68). This outstanding role of law indicates a close similarity between the debates on international legalization and transnational regulation. Yet, the immediate question that arises is what kind of law may take the pivotal role in transnationalized environments: international law or domestic laws? At the international level, Lessig's prominent role of law is at odds with the theory and practice of international cooperation. On the one hand, anarchy as the absence of hierarchical constellation is a central tenet in international relations. On the other hand, delegation of competences to supranational authorities remains the exception rather than the rule-the European Union and to a lesser extent the World Trade Organization's dispute settlement body being the exceptions (Jönsson 2002). At the same time, the extraterritorial application of domestic laws has gained importance in recent years. In the realm of regulation of transnational spaces, it is often the European Union that has joined the United States and its established history to extend the reach of its provisions beyond its borders (Selin and VanDeveer 2006). And yet, the externalization of domestic laws tends to be more a source for conflict rather than an ordering mechanism (Hoekman and Kostecki 2001; Kobrin 2004; Trachtman 1997). Already this brief discussion indicates that there is a strong inclination to the state and to state-made law in Lessig's interpretation. With this feature, the approach is characterized by a top-down character that may best be subsumed into Hood's category of instruments.

To sharpen the edge of Lessig's first category of ordering and control, it seems promising to broaden the category law. In contrast to Lessig, who basically limits his conception of law to state law, it seems helpful to collapse Ellickson's types of third-party control into one category and to speak of hierarchy rather than law-despite the fact that the pure terminology might 
raise concerns of international relations scholars who see the absence of a superior power as a central feature of their discipline. Hierarchy rather than law allows for incorporating a broader variety within this control mode that refers to the form rather than to the source. As a basic category, hierarchy as a mode of ordering can be found in institutional economics (Williamson 1975) as well as in organization theory (Morstein Marx 1965; Weber 1980). It describes patterns of interaction characterized by a power asymmetries and formal relationships of subordination. Although hierarchy is neither limited to the state nor to law as a means of enforcement, both the formality of asymmetric relationships and an institutionalized mechanism of enforcement are of importance.

Second, the category of market needs to be broadened to achieve a more general and inclusive ideal type. Competition describes a broader mode of control than market. Mostly, competition relates to a pattern of interaction characterized by opposing interests and a rivalry for scarce resources or goods, and price signals are the means to adjust the demand and a supply side of the competitive constellation. To capture more than just economic market interactions, it is helpful to operate with a broader interpretation of competition. If we address, for instance, rivalries in quasi-markets (for instance in the realm of higher education), the logic of price signals alone has a lesser explanatory value. Rather, reputation becomes an important asset. In a similar vein, there are noneconomic markets, with political markets being the best examined example, that operate with still another currency. Examples for political markets are political competition or regulatory competition between political systems or performance competition between states or substate units. With respect to the first, mobile factors such as finance or taxpaying companies are the decisive means of market selection. With respect to the latter, comparative processes of either benchmarking or best practices spur reputation related rankings and learning processes respectively (Benz 2007).

Third, the concept of norms as the generic term, including a variety of nonlegal, standards and guidelines, implies a community-based control mode that "involves social or group standards, peer-based information gathering and behaviour modification based on social sanctions such as ostracisation or disapproval" (Murray and Scott 2002: 503). While, in sociology, community figured for a long time as a descriptor of a premodern pattern of societal ordering (Tönnies 1991), the concept has been adapted to describe ordering based on shared values, trust, and membership in different contexts in the domestic realm (Ouchi 1980; Streeck and Schmitter 1985). For the present, however, to limit the understanding to the domestic context would restrict the concept too much, as I am interested in the way in which transnationalized settings are governed. As a consequence, it seems necessary to relax the membership assumption and to broaden the understanding of community beyond a narrow understanding of family, local groups, or associations. What is more, I suggest operating with a pluralist understanding of norms 
that are either generally accepted or at least accepted by some parts of an "internationalised community." For instance, human rights have achieved an almost universal acceptance, while specific forms of forest management have not. The broader concept of community and its norms also allows for incorporating Ellickson's first control category into our analysis. The personal in "personal ethics" may however be interpreted beyond the individual actor and may include also values and attitudes of corporate and collective actors (Gunningham, Thornton and Kagan 2005).

Finally, the most intriguing innovation in Lessig's typology is the introduction of architecture as a mode of ordering. In his usage, architecture refers basically to code principles of software infrastructures and technologies (see also Holitscher and Hoffmann 2004; Radin 2004). Architecture as a control and enforcement device encompasses however a broader range of issues. The awareness of physical features of architecture has not only a long history in criminal matters (Foucault 1977), but also is of high relevance in contemporary policies. For instance, Kaytal addresses different architectural mechanisms such as natural surveillance, that is, the use of architecture to create spaces that are easily viewed by residents, neighbors, and bystanders, to highlight the potential of nonstandard law enforcement methods in criminal law (Kaytal 2002). Given the broader range of possible empirical cases, design is a broader concept than architecture with which we can describe a control mode based on features build into a specific format, product, or process with the potential to sanction the behavior of individuals (Murray and Scott 2002: 503).

In contrast to Lessig's privileging of the concept of law, I do not assume that any of the four modes of control is more encompassing, dominant, or has a higher explanatory value. The four ideal types are distinctive, not overlapping and self-standing. As a set, they are meant as analytical tools to identify underlying logics in patterns of interaction. Put differently, hierarchy, competition, community, and design are ideal-typed modes of control that are basically expected to complement each other rather than crowd each other out. Accordingly, I share the view that "regulatability" includes law and economics and normative values and architecture" (Mardsen 2000: 625). What is more, I assume that in reality different mechanisms, often combined in different constellations, structure interactions in transnational regulatory spaces. As a consequence, I assume that my interest in tracing control modes in the overlap between the "fourth strata of international law" (Weiler 2001) and "regulatory fields" in "global regulatory capitalism" (Djelic and Sahlin-Andersson 2006; Levi-Faur and Jordana 2005) will reveal a substantial variety of patterns, including singles, pairings, threesomes, and even a foursome constellations.

With mixed modes of control being the rule rather than the exception (Benz 2007: 23; Murray and Scott 2002: 504), the question emerges how hybrids forms of regulation operate and whether under specific conditions one mode or a specific combination tends to dominate. The following 
empirical cases are meant to provide some empirical observation to answer these questions. In particular, they illustrate the way in which the ideal types and their respective operational logic may be related to each and contribute to specific outcomes. Moreover, they should also indicate patterns of hybridization in transnational regulatory spaces.

\section{PATTERNS OF CONTROL ACROSS LEVELS AND ARENAS}

The purpose of the following illustrations is not a detailed presentation of cases. Rather, my focus here is on the different control mechanisms and the way in which they establish links across different geographical level and actors from different arenas. Given this objective, the cases briefly present the background of the problems at stake and then address the core issue of control modes.

\section{A. (FROM) COMMUNITY (TO) HIERARCHY AND COMPETITION: ORGANIC FARMING $^{8}$}

The political economy of organic farming has changed significantly over the past two decades. What started as a local response of a few farmers in wealthier countries against the growing trend toward intensive agriculture has increasingly attracted consumer and environmentalist alike. Alongside the increase on the demand side, the level of activity of organic farming has shifted from the local to the national and international. In addition, changing market structures also involved an increasing number of actors in the market for organic farming and a differentiation of producer sizes. According to Coleman and Reed, by 2002 the total global market for organic food was estimated at U.S.\$23 billion, and it is expected to reach a level of about U.S.\$102 billion by 2010 (2007: 104-06).

The growing complexity of organic farming is also reflected in an increase of efforts to provide accepted standards for organic products. While in the beginning organic producers and their transnational associations developed their standards, over time they were joined by states engaging in standardization and certification. More precisely, three dimensions must be distinguished: governments set national standards for organic production; they also set the rules for the accreditation of organizations that in turn are attributed the right to certificate products as being produced in accordance with the standards for organic production. Thus, governments rely on private bodies to for deciding about the organic property of a product (ibid.: 108).

For instance, in the United States, the Department of Agriculture (USDA) operates on the basis of the Organic Foods Production Act when it regulates organic products and process. While standard-setting in the realm of the USDA is largely in the hands of a special board that incorporates a variety of stakeholders, compliance with and enforcement of national 
standards is in the hands of organizations that build the chain of accrediting and certification. Indeed, the USDA only deals with so-called "accredited certifying agents" that totalled to about 100 companies by 2002. The accredited certifying agents review applications for the status of a certification agent for organic food, they make site-visits on farms and handling operators, they issue certificates to operators, and they are responsible for complaints in the realm of certification. While most of the accredited certifying agents are private organizations, a quarter are state departments of agriculture. Another interesting feature relates to the extraterritorial activity of these accredited certifying agents. There is a group of organizations listed as "foreign accredited certifying agents"-including agencies from other countries. These organizations "operate in countries other than the U.S. and are involved in the certification of organic products that are later imported into the U.S." (ibid.: 110).

Similar to the U.S. example, other major importing jurisdictions (Canada, European Union, Japan) require that products from developing countries need to be certified as organic before they may be imported. However, the criteria for certification differ from country to country. And so do the institutional settings in the accreditation and certification chain. For instance, the Canadian regulations are more based on private organizations and a voluntary approach than that in the United States. Only Québec has a mandatory system of accreditation and certification, whereas in all other provinces, private sector organizations dominate. However, there seems to be a debate on the deficiencies or even the general lack of enforcement mechanisms at the national level (ibid.: 110; for an overview of practice and differences, see Bowen 2004).

In addition to different national standards and procedures that also spread into the international realm, the legal diversity of different standards and procedures is even more pronounced at the international level. The complex situation involves not only states and their extraterritorial practices, but also international organizations such as the International Standardization Organization, the Codex Alimentarius Commission (the food and agriculture organization of the United Nations World Health Organization), and the private International Federation of Organic Agriculture Movements (IFOAM; the traditional representative of the original organic food producers). While there are some forms of cooperation between the different bodies and organizations (for instance in the realm of harmonization of standards), there is substantial competition between organizations, their standards, and the underlying philosophies. What is of interest for the present context is that in contrast to the provision of the Codex Alimentarius Commission, the IFOAM standards list additional provisions relating to accreditation and enforcement (ibid.: 112).

In sum, the example of organic food provides a specific mix of control mechanisms, involving community, hierarchy, and competition. With the international growth of both the demand and supply side for organic products, 
the original local and community-based approaches shifted more and more to the margins. Instead, the legal diversity is characterized by hierarchies either in the form of state-based law or by private organizations such as the IFOAM and its provisions on accreditation and enforcement. The acts of accreditation and certification are the most important dimension in the process of control and enforcement. The competitive dimension relates to both the competition between public and private arrangements at an international scale. Consumers may have the choice between different certified products, and producers may seek to be certified by according to different standards. There are, however, limits to these choices. Especially farmers in developing countries may find the standards and practices of control being insurmountable obstacles (Bowen 2004).

\section{B. HIERARCHY AND DESIGN: DOMAIN NAME VS. TRADEMARKS CONFLICTS}

As a worldwide network of computer networks, an integral part of the communication on the Internet rests on a system that enables the unequivocal addressing of each single computer. The domain name system is based on numeric identifiers, the Internet protocol addresses that, as a matter of convenience, are coupled with alphanumeric counterparts usually referred to as domain names. While in the beginning the assignment of domain names was carried out free of charge on a first-come, first-served basis, commercialization transformed the nature of the domain name system. Domain names that had mainly been user-friendly addresses have turned more and more into tradable commodities and brand names. As many domain names bear the characteristics of established brand names, conflicts at the interface between domain names and trademarks were unavoidable. At the same time, the geographic and sector principles of trademark law map badly onto the Internet's architecture that ignores both national borders and sectors.

Since the mid-1990s a growing number of firms have realized the economic importance of domain names, when they discovered that their preferred names were already registered by others. These others were not always firms with an equally "legitimate" claim to a domain, but also "pirates" or "cybersquatters" grabbing a well-known domain name in order to make money by selling it to the trademark owner at an inflated price (Thornburg 2000: 160). With the mandate of the U.S. government (and later by its general assembly), the World Intellectual Property Organization (WIPO) organized a process of international deliberation to design a proposal to solve domain name versus trade mark conflicts in a transnational uniform scheme. WIPO handed its recommendation to the Internet Corporation for Assigned Names and Numbers (ICANN), a nonprofit organization under Californian law bestowed with the authority to administer and regulate the Internet domain name system by the U.S. government since November 1998. ICANN reviewed the proposal and its Uniform Domain Name Dispute 
Resolution Policy and Rules for Uniform Domain Name Dispute Resolution (UDRP) went into effect (see Helfer and Dinwoodie 2001; Murray 2007).

The UDRP provides a quick and relatively inexpensive forum for parties to challenge domain name holders' rights to a name. Under UDRP rules, someone who believes that her rights were violated by a particular domain name registration (complainant) initiates the dispute and chooses one of the four the dispute service providers approved by ICANN. ${ }^{9}$ If the decision is made in favor of the complainant, ICANN rules require a cancellation of the domain name or a transfer to the complainant. No monetary remedies are awarded. Until early 2007, the approved dispute resolution providers had resolved roughly 10,600 cases involving more than 18,000 domain names.

A summary of the features of the way in which conflicts at the interface between domain names and trademarks are settled may read as follows. First, in contrast to decentralization as the basic architectural principle of the Internet, the domain name system with its need for uniqueness is one of the very few areas that requires centralization. Bestowed with the authority to manage and maintain the domain name system, ICANN is equipped with a de facto monopoly that allowed for a centralization of authority via the establishment of a contractual system that involves all relevant actors and interest in the generic Top Level Domains. Second, the contractual regime also allowed for making the Uniform Dispute Resolution Policy mandatory for everyone interested in registering domain name in the most prominent generic Top Level Domains. Conflicts in these domains are subjected the UDRP, with the actual resolution of conflicts being delegated by ICANN to a number of different public and private organizations. ${ }^{10}$ Third, the contractual regime and the mandatory conflict resolution procedure are complemented by the capacity to implement decisions of tribunals without reference to any further authority. Rather, once a final judgment is made, the technical infrastructure of the Internet's domain name system allows for a self-execution of the judgment. Thus, self-executive titles are the particularity when it comes to implementation. Hence, hierarchy and technical code are the mechanisms that characterize the administration of the domain name system and the resolution of conflicts at the interface between the Internet's domain name system and the global trademark regulation.

\section{COMMUNITY AND COMPETITION: COMPANY CODES OF CONDUCT}

With the increase of economic exchange around the globe, often addressed as globalization, transnational companies have moved to the center of attention. Alongside the rapid increase in the number and size of transnational corporations, their visibility has increased and so have concerns about the social, environmental, and developmental impact of their activities. Following the claim that prices do not reflect the true social and environmental costs of their activities, there is the call for a regulation of transnational companies (e.g., FitzGerald 2001). 
Faced with increasing pressure, many companies have started to accept a model that shifts their role in international affairs from being a global bourgeois to a global citoyen, implying a role model that accommodates the strategy of benefit maximizing with social responsibility voluntary contributions made by a company to community development both at home and abroad (Scherer 2003). In contrast to the 1970s, however, contemporary governments are much less willing to intervene by designing international provisions. Rather, voluntary initiatives have gained more and more prominence. Despite some countries' introduced provisions on social and environmental reporting, the voluntary dimension is of utmost importance in corporate self-regulation in the efforts of companies to improve their working conditions, environmental performance, and more generally, their relationship with customers, local communities, activists, and other stakeholders.

The momentum that the so-called social corporate responsibility movement (Haufler 2001) has gathered finds expression also in the proliferation of corporate codes of conduct. The Organization for Economic Cooperation and Devlopment (OECD) identified no less than 246 different codes of conduct (OECD 2000). Codes can be divided into five main types: company codes, trade association codes, multistakeholder codes, model codes, and intergovernmental codes (Jenkins 2001). The proliferation of codes of conduct does not include all companies in all sectors alike. Rather there are some remarkable patterns: first, codes of conduct are more important in exporting industries; second, codes are significantly more prominent in certain sectors, in particular textiles, chemicals, and extracting industries; third, codes addressing labor issues are more prominent in garment industries, footwear, sporting goods, toys, and retailing, whereas environmental codes are more likely to be found in chemicals, forestry, oil, and mining (Nadvi and Wältring 2002).

Voluntary regulation and corporate social responsibility have been criticized from two different angles. For some they are either a hype or a threat that risks reducing both profits and social welfare (see The Economist 2005), while other point at implementation and enforcement as the Achilles heel of voluntary self-regulation via codes of conduct: According to an estimation of the International Organization of Employers, 80 percent of codes are statements about general business ethics but lack statements on implementation, and only 10 percent of the codes listed in the OECD inventory provided for external monitoring (Jenkins 2001; O'Rourke 2000). This is, however, not the place to engage in the assessment of voluntary initiatives, and I will leave attempts to improve the outcome of voluntary initiatives and transnational business self-regulation to others (see, e.g., the contribution in Gunningham and Kagan 2005). Rather, my interest in the case of company codes of conduct relates to the governing principles.

The example of codes of conduct guiding the social and environmental performance of transnational companies may be interpreted as a case in which community and competition, as control modes play a role. On the one hand, the proliferation of voluntary self-regulation of companies may 
be related to the significant pressure of nongovernmental organizations and consumer boycotts. Although both factors have in various cases exerted significant pressure on the valuation and reputation of companies (Fuchs 2005), the uneven spread of codes indicates that community values and norms have only a limited impact the new role model of "business in society." An additional factor that might exert pressure in this direction stems from financial markets. The more transnational companies compete in international capital markets, the more they have to be aware of signals from financial markets and international investors. In this respect, the policy of many large institutional investors such as pension funds or specialized private groupings to put more emphasis on the general compatibility between sustainable business practices, on the one hand, and a long-term perspective in funds management, on the other, provides a market momentum (to minimize reputation threats for a company) that reinforces the community impulse toward a greater responsibility of firms for social and environmental concerns.

\section{CONCLUSION}

The purpose of the article was to elaborate on overlaps in, so far, largely unrelated research programs of the legalization in international relations, on the one hand, and transnational regulation and governance, on the other. As it turned out, the literatures at the interface between the "fourth strata of the geology of international law" and the "governance in the age of regulation" have a substantial common interest in policy issues, actors, and forms of interaction. While promising to be an intellectually highly fruitful enterprise, to address these overlaps poses some conceptual challenges for the respective academic literatures due to limitations inherent in either of the two. With the objective to show a possible way of accommodating the respective analytical strengths while covering the blind spots, I elaborated on four ideal types of control modes in transnational regulatory spaces: hierarchy, market, community, and design. These analytical tools were then used to analyze some empirical cases. I would like to end my considerations by pointing at two findings of the analysis.

First, in transnational regulatory spaces, a hybridization of control modes is more likely than their individual operation. In particular, three dimensions of hybridization have been identified: hybrids between different control mechanisms; hybrids between public and private governance; and hybrids between different levels of governance, that is, the regional, national, and transnational level. As a consequence, complex patterns rather than simple models seem to be the feature of transnational governance. The present cases nicely illustrated some ways in which the blending of different modes of control may occur. Organic farming, for instance, showed how, over time, national legislation and transnational norms have replaced a pattern 
of control that originally was local and community-based in substance and form. What is more, in this process, private and public contributions have become increasingly interwoven, and the competition on the supply side of organic products offers consumers significant choices. In contrast, ICANN's administration of the Internet domain name system has from the beginning been built on a blending of public and private contributions, with the public contribution deriving from the de facto power of an individual state. Backed by this national public authority, the technical properties of the domain name system's infrastructure allow for a centralized private control of a global network good. Finally, the story of control of company codes of conduct has been interpreted as a case in which community norms have increasingly been transnationally defined and controlled. The specific blending of the control dimension relates to the way in which norm-related reputation and the threat of respective damages have become an important dimension in the market competition between firms for consumers and financial investors alike.

Second, hierarchy has been identified as an important control mechanism in transnational regulation. This might be in contrast to the traditional assumption of international relations theories that supposes anarchy as the absence of a hierarchical relationship in the international realm. Yet, a closer look might help to reveal that the hierarchy as control means is not the kind of hierarchy international relations scholars usually look for. Rather than being related to a superior authority beyond state level, hierarchy may refer to a constellation in which domestic regulations purposefully radiate into the international realm. In this regard, hierarchy as a control mode is particularly powerful when it is combined with the dynamics of political competition for markets and economic competition in markets. As has been illustrated by the case of organic food regulation, jurisdictions with important markets such as the United States, the European Union, or Japan may exert sufficient power so that their domestic provisions gain international importance. In the case of control and enforcement of disputes between Internet domain names and trademarks, it was the hegemonic behavior of the United States that, based on the privileged control over important technical infrastructure, has led to the investiture of a hierarchy. As a consequence, U.S. law and design principles of the domain name system combine to a quite rigid transnational regulatory arrangement in a private disguise. As a consequence, it seems necessary to bring power differentials and their impact on regulatory structures as a traditional theme of the international relations literature back into the analysis of transnational regulatory spaces.

DiRK Lehmkuhl is Professor for European Politics at the University of St. Gallen, Switzerland. His teaching and research portfolio include comparative European and international public policies, the role of nonstate actors in transnational relations, and the analysis of the interaction of different regulatory contributions in global governance. 


\section{NOTES}

1. Transnational relations are defined as "the movement of tangible and intangible items across state boundaries when at least one actor is not an agent of a government or an intergovernmental organization" (as opposed to international relations which occur between state actors) (Nye and Keohane 1972: xii).

2. The first strata encompasses bilateral treaties, the second strata by multilateral treaties, and the third strata customs and general principles of international law (Weiler 2001, quoted in Suh 2002: 612).

3. To be clear, the focus in the present context is not on so-called soft law that derives from the increasing state practice to place normative statements in legally nonbinding political instruments such as resolutions or declarations (Shelton 2008).

4. As will be shown below in more detail, however, the reference to the domestic context is important because here regulatory arrangements operate in the more or less explicit shadow of it - a condition that we cannot expect in transnational regulatory spaces.

5. However, in more recent accounts we can find a much stronger interest in the factors explaining differences across sectors and countries (Gilardi 2005a: 139_ 67, 2005b: 84-101).

6. As aptly noted by Murray and Scott, an analysis of modes of governance does not fuel by itself decisions on institutional design or instrumental choices (2002).

7. The following is based on Coleman and Reed (2007).

8. By May 2000: the National Arbitration Forum (NAF), the World Intellectual Property Organization, CPR Institute for Dispute Resolution, and eResolution. Since December 2001, however, there have been two changes. On the one hand, eResolution has folded its operations due to a lack of cases by the end of November 2001, and, on the other hand, on 3 December 2001 ICANN announced the accreditation of the Asian Domain Name Dispute Resolution Center as a new provider that was expected to begin accepting disputes on 28 February 2002 through offices in its centres in Beijing and Hong Kong.

9. The approved providers are listed at the ICANN. Available at http:// www.icann.org/dndr/proqcp/approved-providers.htm (accessed 11 March 2008).

10. The idea of "business in society" can be related to Ellickson's first party controller (1991).

\section{REFERENCES}

Abbott, Kenneth W., and Duncan Snidal (2001) "Hard and Soft Law in International Governance." In Legalization and World Politics, edited by J. Goldstein et al. Cambridge, MA: The MIT Press.

Abbott, Kenneth W., and Duncan Snidal (2002) "Values and Interests: International Legalization in the Fight Against Corruption," Journal of Legal Studies 31: 141-78.

Ayling, Julie, and Peter Grabosky (2006) "Policing by Command: Enhancing Law Enforcement Capacity Through Coercion," Law \& Policy 28: 420-43.

Ayres, Ian, and John Braithwaite (1992) Responsive Regulation: Transcending the Deregulation Debate. New York: Oxford Univ. Press.

Bartley, Tim (2003) "Certifying Forests and Factories: States, Social Movements, and the Rise of Private Regulation in the Apparel and Forest Products Fields," Politics \& Society 31: 433-62.

Benz, Arthur (2007) "Politischer Wettbewerb." In Handbuch Governance. Theoretische Grundlagen und empirische Handlungsfelder, edited by A. Benz et al. Wiesbaden: VS Verlag. 
Bernstein, Steven, and Benjamin Cashore (2004) "Non-State Global Governance: Is Forest Certification a Legitimate Alternative to a Global Forest Convention?" In Hard Choices, Soft Law. Voluntary Standards in Global Trande, Environment and Social Governance, edited by J. J. Kirton \& M. J. Trebilkock. Aldershot, UK: Ashgate.

Black, Julia (1997) Rules and Regulators. Oxford: Clarendon Press.

Bowen, Diane (2004) Current Mechanisms that Enable International Trade in Organic Products: Discussion Paper. International Task Force on Harmonization and Equivalence in Organic Agriculture. International Federation of Organic Agriculture Movements. Available at http://r0.unctad.org/trade_env/test1/meetings/itf1.htm (accessed 11 March 2008).

Braithwaite, John, and Peter Drahos (2000) Global Business Regulation. Cambridge: Cambridge Univ. Press.

Bruce Hall, Rodney, and Thomas J. Biersteker (eds.) (2002) The Emergence of Private Authority in Global Governance. Cambridge: Cambridge Univ. Press.

Brütsch, Christian, and Dirk Lehmkuhl (eds.) (2007) Law and Legalization in Transnational Relations. London: Routledge.

Checkel, Jeffrey T. (1999) "Why comply? Constructivism, Social Norms, and Study of International Institutions," Arena Working Paper 99/24. Available at http:// www.arena.uio.no/publications/working-papers1999/papers/wp99_24.htm (accessed 11 March 2008).

Coleman, James S. (1990) Foundations of Social Theory. Cambridge: Belknap Press.

Coleman, William D., and Austina J. Reed (2007) "Legalisation, Transnationalism and the Global Organic Movement." In Law and Legalization in Transnational Relations, edited by C. Brütsch \& D. Lehmkuhl. London: Routledge.

Cutler, A. Claire, Virginia Haufler, and Tony Porter (eds.) (1999) Private Authority and International Affairs. New York: State Univ. of New York Press.

Daintith, Terence (1994) "The Techniques of Government." In The Changing Constitution, edited by J. Jowell \& D. Oliver. Oxford: Clarendon Press.

Diehl, Paul F., Charlotte Ku, and Daniel Zamora (2003) "The Dynamics of International Law: The Interaction of Normative and Operating Systems," International Organization 57: 43-76.

Djelic, Marie-Laure, and Kerstin Sahlin-Andersson (2006) Transnational Governance in the Making-Regulatory Fields and their Dynamics. Cambridge: Cambridge Univ. Press.

Drezner, Daniel W. (2004) "The Global Governance of the Internet: Bringing the Great Powers Back In," Political Science Quarterly 119: 477-98.

Ellickson, Robert C. (1991) Order Without Law. How Neighbours Settle Disputes. Cambridge, MA: Harvard Univ. Press.

Finnemore, Martha, and Kathryn Sikkink (2001) "Taking Stock: The Constructivist Research Program in International Relations and Comparative Politics," Annual Review of Political Science 4: 391-41.

FitzGerald, Valpy (2001) Regulating Large International Firms. Paper given at UNRISD Workshop Promoting Corporate Responsibility in Developing Countries: The Potential and Limits of Voluntary Initiatives. Geneva (23-24 October 2000). Available at http://www.unrisd.org/unrisd/website/document.nsf/ (httpPublications)/5750D0DD9A373C8D80256B5E0034EF43?OpenDocument (accessed 11 March 2008).

Fligstein, Neil (2001) The Architecture of Markets: An Economic Sociology of TwentyFirst-Century Capitalist Societies. Princeton, NJ: Princeton Univ. Press.

Foucault, Michel (1977) Discipline \& Punish: The Birth of the Prison. London: Penguin Books Ltd.

Fuchs, Doris (2005) "Commanding Heights? The Strength and Fragility of Business Power in Global Politics," Millenium 33: 771-803. 
Gilardi, Fabrizio (2005a) "The Formal Independence of Regulators: A Comparison of 17 Countries and 7 Sectors," Swiss Political Science Review 11: 139-67.

Gilardi, Fabrizio (2005b) "The Instituional Foundations of Regulatory Capitalism: The Diffusion of Independent Regulatory Agencies in Western Europe," The Annals of the American Academy of Political and Social Science 598: 84-101.

Goldstein, Judith, Miles Kahler, Robert O. Keohane, and Anne-Marie Slaugther (eds.) (2001) Legalization and World Politics. Cambridge, MA: MIT Press.

Grabosky, Peter (1995) "Using Non-Governmental Resources to Foster Regulatory Compliance," Governance 8: 527-50.

Gunningham, Neil, and Peter Grabosky (1998) Smart Regulation. Oxford: Clarendon Press.

Gunningham, Neil, and Robert A. Kagan (2005) "Regulation and Business Behavior," Law \& Policy 27: 213-18.

Gunningham, Neil A., Dorothy Thornton, and Robert A. Kagan (2005) "Motivating Management: Corporate Compliance in Environmental Protection," Law \& Policy 27: $289-316$.

Haas, Peter M. (1992) "Introduction: Epistemic Communities and International Policy Coordination," International Organization 46: 1-35.

Harter, Philip J., and Georg C. Fads (1985) "Policy Instruments, Institutions, and Objectives: An Analytical Framework for Assessing 'Alternatives' to Regulation," Administrative Law Review 37: 221-58.

Hasenclever, Andreas, Peter Mayer, and Volker Rittberger (2000) "Integrating Theories of International Regimes," Review of International Studies 26: 3-33.

Haufler, Virginia (2001) A Public Role for the Private Sector: Industry Self-regulation in Global Economy. Washington DC: Carnegie Endowment for International Peace.

Hedström, Peter, and Richard Swedbergrd (eds.) (1998) Social Mechanism. An Analytical Approach to Social Theory. Cambridge: Cambridge Univ. Press.

Helfer, Laurence R., and Graeme B. Dinwoodie (2001) "Designing Non-National Systems: The Case of the Uniform Donaim Name Dispute Resolution Policy," William and Mary Law Review 48: 141-273.

Hoekman, Bernard M., and Michael M. Kostecki (2001) The Political Economy of the World Trading System. The WTO and Beyond. Oxford: Oxford Univ. Press.

Holitscher, Marc, and Jeanette Hoffmann (2004) "Zur Beziehung von Macht und Technik im Internet." In Soziologie des Cyberspace. Medien, Strukturen und Semantiken, edited by U. Thiedeke. Wiesbaden: Verlag für Sozialwissenschaften.

Hood, Christopher (1983) The Tools of Government. London: Macmillan.

Hood, Christopher (2007) "Intellectual Obsolenscence and Intellectual Makeover: Reflections on the Tools of Government After Two Decades," Governance 20: 127 44.

International Court of Justice. Statute of the International Court of Justice. Available at http://www.icj-cij.org/documents/index.php?p1=4\&p2=2\&p3=0 (accessed 11 March 2008).

Jenkins, Rhys (2001) Corporate Codes of Conduct: Self Regulation in a Global Economy: Paper No.: 2. Geneva: United Nations Research Institute for Social Development (UNRISD). Available at http://www.unrisd.org/80256B3C005BCCF9/ (httpPublications)/E3B3E78BAB9A886F80256B5E00344278?OpenDocument\&panel =seriespapers (accessed 11 March 2008).

Jönsson, Christer (2002) "Diplomacy, Bargaining and Negotiation." In Handbook of International Relations, edited by W. Carlsnaes, T. Risse \& B. Simmons. Thousand Oaks, CA: Sage Publications.

Jordana, Jacint (2005) "Book Review Essay: Globalizing Regulatory Capitalism," The Annals of the American Academy of Political and Social Science 598: 18490. 
Jordana, Jacint, and David Levi-Faur (eds.) (2004) The Politics of Regulation. Institutions and Regulatory Reform in the Age of Governance. Cheltenham, UK: Edward Elgar.

Kahler, Miles (2001) "Conclusion: The Causes and Consequences of Legalization." In Legalization and World Politics, edited by J. Goldstein, M. Kahler, R. O. Keohane \& A.-M. Slaugther. Cambridge, MA: MIT Press.

Kaiser, Karl (1969) "Transnationale Politik." In Die anachronistische Souveränität, edited by E.-O. Czempiel. Köln, Germany: Westdeutscher Verlag.

Kaytal, Neil Kumar (2002) "Architecture as Crime Control," Yale Law Journal 11: 1039-139.

Keohane, Robert O. (1997) "International Relations and International Law: Two Optics," Harvard International Law Journal 38: 487-502.

Keohane, Robert O., and Joseph S. Nye (1971a) "Transnational Relation and World Politics: An Introduction," International Organization 25: 329-50.

Keohane, Robert O., and Joseph S. Nye (1971b) "Transnational Relations and World Politics," International Organization 25: 721-49.

Kirton, John J., and Michael J. Trebilkock (eds.) (2004) Hard Choices, Soft Law. Voluntary Standards in Global Trade, Environment and Social Governance. Aldershot, UK: Ashgate.

Knill, Christoph, and Dirk Lehmkuhl (2002) "Private Actors and the State: Internationalization and Changing Patterns of Governance," Governance: An International Journal of Policy, Adminstration and Institutions 15: 41-63.

Kobrin, Stephen J. (2004) "Safe Harbours Are Hard to Find: The Trans-Atlantic Data Privacy Dispute, Territorial Jurisdiction and Global Governance," Review of International Studies 30: 111-31.

Kooiman, Jan (eds.) (1993) Modern Governance. New Government-Society Interactions. London: Sage.

Kooiman, Jan (1999) "Socio-Political Governance. Overview, Reflections and Design," Public Administration 1: 68-92.

Krasner, Stephen D. (1983) "Structural Causes and Regime Consequences: Regimes as Intervening Variables." In International Regimes, edited by S. D. Krasner. Ithaca, NY: Cornell Univ. Press.

Krasner, Stephen D. (1999) Sovereignty: Organized Hypocrisy. Princeton, NJ: Princeton Univ. Press.

Kratochwil, Friedrich V. (1989) Rules, Norms, and Decisions. Cambridge: Cambridge Univ. Press.

Kratochwil, Friedrich V. (2000) "How do Norms Matter?" In The Role of Law in International Politics. Essays in International Relations and International Law, edited by M. Byers. Oxford: Oxford Univ. Press.

Lascoumes, Pierre, and Patrick Le Gales (2007) "Introduction: Understanding Public Policy Through Its Instruments-From the Nature of Instruments to the Sociology of Public Policy Instrumentation," Governance 20: 1-21.

Lessig, Lawrence (1998) "The New Chicago School," Journal of Legal Studies 27: 661-91.

Lessig, Lawrence (1999) Code and Other Laws of Cyberspace. Basic Books.

Levi-Faur, David (2005) "The Global Diffusion of Regulatory Capitalism," The Annals of the American Academy of Political and Social Science 598: 12-32.

Levi-Faur, David, and Jacint, Jordana (2005) "Preface: The Making of a New Regulatory Order," The Annals of the American Academy of Political and Social Science 598: 6-11.

Levine, Michael E., and Jennifer L. Forrence (1990) "Regulatory Capture, Public Interest, and the Public Agenda: Toward a Synthesis," Journal of Law, Economics, \& Organization, 6 (Special Issue: Papers from the Organization of Political Institutions Conference, April): 167-80.

Majone, Giandomenico (eds.) (1996) Regulating Europe. London and New York: Routledge. 
Mansbach, Richard M., Yale H. Ferguson, and Donald E. Lampert (1976) The Web of World Politics. Nonstate Actors in the Global System. Englewood Cliffs, NJ: Prentice-Hall.

Mardsen, Christopher T. (2000) "Review of Lawrence Lessig. Code Is Law," Modern Law Review 63: 424-628.

Mayntz, Renate (2004) "Governance Theory als fortentwickelte Steuerungstheorie?" MPIfG Working Paper 04/1, März 2004. Max-Planck-Institut für Gesellschaftsforschung. Available at http://www.mpifg.de/pu/workpap/wp04-1/wp04-1.html (accessed 11 March 2008).

Morgan, Bronwen, and Karen Yeung (2007) An Introduction to Law and Regulation. Cambridge: Cambridge Univ. Press.

Morstein Marx, Fritz (1965) "Hierarchie und Entscheidungsweg." In Verwaltung. Eine einführende Darstellung, edited by F. Morstein Marx. Berlin: Duncker \& Humblot.

Murray, Andrew D., and Colin Scott (2002) "Controlling the New Media: Hybrid Responses to New Forms of Power," Modern Law Review 65: 491-516.

Murray, Andrew D. (2007) The Regulation of Cyberspace: Control in the Online Environment. London: Routledge Cavendish.

Nadvi, Khalid, and Frank Wältring (2002) "Making Sense of Global Standards." In INEF Report, Heft 58/2002, edited by Institut für Entwicklung und Frieden der Gerhard-Mercator-Universität Duisburg. Duisburg. Available at http://inef.unidue.de/page/documents/Report58.pdf (accessed 11 March 2008).

Neyer, Jürgen, and Michael Zürn (2001) "Compliance in Comparative Perspective. The EU and Other International Institutions," InIIS-Arbeitspapier 23. Bremen, Germany: Institut für Interkulturelle und Internationale Studien.

Nye, Joseph, and Robert O. Keohane (eds.) (1972) Transnational Relations and World Politics. Cambridge, MA: Harvard Univ. Press.

OECD (2000) Codes of Corporate Conduct: An Expanded Review of Their Contents. OECD Working Party of the Trade Committee (TD/TC/WP(99)56/Final). Paris: OECD. Available at: http://www.olis.oecd.org/olis/1999doc.nsf/ENGDATCORPLOOK/NT00002A4A/\$FILE/00078855.PDF (accessed 11 March 2008).

O'Rourke, Dara (2000) Monitoring the Monitors: A Critique of PriceWaterhouse Coopers $(P w C)$ Labor Monitoring. Cambridge: Cambridge Univ. Press.

Ogus, Anthony (1995) "Rethinking Self-Regulation," Oxford Journal of Legal Studies 15: 97-108.

Ouchi, William G. (1980) "Markets, Bureaucracies, and Clans," Administrative Science Quarterly 25: 129-41.

Parker, Christine, Colin Scott, Nicola Lacey, and John Braithwaite (eds.) (2004) Regulating Law. Oxford: Oxford Univ. Press.

Radin, Margret Jane (2004) "Regulation by Contract, Regulation by Machine," Journal of Institutional and Theoretical Economics 160: 1-15.

Reus-Smit, Christian (2004a) "The Politics of International Law." In The Politics of International Law, edited by C. Reus-Smit. Cambridge: Cambridge Univ. Press.

Reus-Smit, Christian (ed.) (2004b) The Politics of International Law. Cambridge: Cambridge Univ. Press.

Risse-Kappen, Thomas (ed.) (1995) Bringing Transnational Relations Back In: Non-State Actors, Domestic Structures, and International Institutions. Cambridge: Cambridge Univ. Press.

Risse, Thomas (2002) "Constructivism and International Institutions. Toward Conversations Across Paradigms.” In Political Science as Discipline. Reconsidering Power, Choice, and the State at Centurys End, edited by I. Katznelson \& Helen Milner. New York: W. W. Norton.

Ronit, Karsten, and Volker Schneider (2000) "Private Organizations and Their Contribution to Problem-Solving in the Global Arena." In Private Organizations in Global Politics, edited by K. Ronit \& V. Schneider. London: Routledge. 
Rosenau, James N. (1992) "Governance, Order, and Change in World Politics." In Governance Without Government: Order and Change in World Politics, edited by J. N. Rosenau \& E.-O. Czempiel. Cambridge: Cambridge Univ. Press.

Salamon, Lester M. (2002) "The New Governance and the Tools of Public Action: An Introduction." In The Tools of Government: A Guide to the New Governance, edited by L. Salamon. New York: Oxford Univ. Press.

Scherer, Andreas (2003) Multinationale Unternehmen und Globalisierung. Heidelberg, Germany: Physica.

Schimank, Uwe (2003) "Theoretische Modelle sozialer Strukturdynamiken. Ein Gefüge von Generalisierungsniveaus." In Akteur-Mechanismen-Modelle, edited by R. Mayntz. Frankfurt a. M., Germany: Campus.

Schimank, Uwe (2007) "Elementare Mechanismen." In Handbuch Governance. Theoretische Grundlagen und empirische Anwendungsfelder, edited by A. Benz, S. Lütz \& U. Schimank. Wiesbaden, Germany: VS Verlag.

Scott, Colin (2004) "Regulation in the Age of Governance: The Rise of the PostRegulatory State." In The Politics of Regulation. Institutions and Regulatory Reform in the Age of Governance, edited by J. Jordana \& D. Levi-Faur. Cheltenham, UK: Edward Elgar.

Selin, Henrik, and Stacy D. VanDeveer (2006) "Raising Global Standards. Hazardous Substances and the E-Waste Management of the European Union," Environment 10: 6-17.

Shapiro, Martin, and Alec Stone Sweet (2002) On Law, Politics, and Judicialization. Oxford: Oxford Univ. Press.

Shelton, Dinah (2000) "Law, Non-Law and the Problem of 'Soft Law'." In Commitment and Compliance. The Role of Non-Binding Norms in the International Legal System, edited by D. Shelton. Oxford: Oxford Univ. Press.

Shelton, Dinah (2008) "'Soft Law'," GWU Law School Public Law Research Paper No. 322. The George Washington Univ. Law School. Available at http:// papers.ssrn.com/sol3/papers.cfm?abstract_id=1003387\#PaperDownload (accessed 11 March 2008).

Sinclair, Timothy J. (2005) The New Masters of Capital: American Bond Rating Agencies and the Politics of Creditworthiness. Ithaca, NY: Cornell Univ. Press.

Slaughter, Anne-Marie (2004) A New World Order. Princeton, NJ: Princeton Univ. Press.

Stoker, Gerry (1998) "Governance as Theory: Five Propositions," International Social Science Journal 155: 17-28.

Strange, Susan (1996) The Retreat of the State. The Diffusion of Power in the World Economy. Cambridge: Cambridge Univ. Press.

Streeck, Wolfgang, and Philippe C. Schmitter (1985) "Community, Market, Stateand Associations? The Prospective Contribution of Interest Governance to Social Order." In Private Interest Government. Beyond Market and State, edited by W. Streeck \& P. C. Schmitter. London: Sage Publications.

Suh, Don (2002) "Situating Liberalism In Transnational Legal Space," Duke Journal of Comparative \& International Law 12: 605-30.

Teubner, Gunther (2001) "Global Private Regimes: Neo-spontaneous Law and Dual Constitution of Autonomous Sectors in World Society?" In Public Governance in the Age of Globalization, edited by K.-H. Ladeur. Ashgate, UK: Aldershot.

The Economist (2005) "The Good Company" The Economist, 20 January.

Thornburg, Elisabeth G. (2000) "Going Private: Technology, Due Process, and Internet Dispute Resolution," U.C. Davis Law Review 34: 151-220.

Tönnies, Ferdinand (1991) Gemeinschaft und Gesellschaft: Grundbegriffe der reinen Soziologie. Darmstadt, Germany: Wissenschaftliche Buchgesellschaft.

Trachtman, Joel P. (1997) "Externalities and Extraterritoriality: The Law and Economics of Prescriptive Jurisdiction." In Economic Dimensions in International Law. 
Comparative and Empirical Perspectives, edited by J. S. Bhandari \& A. O. Sykes. Cambridge: Cambridge Univ. Press.

Waltz, Kenneth N. (1979) Theory of International Politics. New York: Random House.

Weber, Max (1980) Wirtschaft und Gesellschaft. Tübingen, Germany: Mohr.

Weber, Max (1991) "Die 'Objektivität' sozialwissenschaftlicher und sozialpolitischer Erkenntnis." In Schriften zur Wissenschaftslehre, edited by M. Weber. Stuttgart: Reclam (first published in Archiv für Sozialwissenschaft und Sozialpolitik 19, 1904). Weiler, Joseph (2001) Towards a Geology of 20th Century International Law: The Paradox of Law Making and Enforcement. Speech at Duke Law School (February 12). Williamson, Oliver E. (1975) Markets and Hierarchies. New York: The Free Press.

Yeung, Karen (2005) "Government by Publicity Management: Sunlight or Spin?" Public Law: 360-83.

Young, Oran R. (1994) International Governance. Protecting the Environment in a Stateless Society. Ithaca, NY: Cornell Univ. Press.

Young, Oran R. (1997) "Global Governance: Toward a Theory of Decentralized World Order." In Global Governance: Drawing Insights From the Environmental Experience, edited by O. R. Young. Cambridge, MA: MIT Press.

Zacher, Mark W., and Brent A. Sutton (1996) Governing the Global Networks. International Regimes for Transportation and Communication. Cambridge: Cambridge Univ. Press.

Zammit, Ann (2003) Development at Risk: Rethinking UN-BusinessPartnerships. Geneva: South Centre/UNRISD.

Zangl, Bernhard, and Michael Zürn (eds.) (2004) Verrechtlichung-Baustein für Global Governance? Bonn, Germany: Dietz.

Zürn, Michael (1998) Regieren jenseits des Nationalstaates. Globalisierung und Denationalisierung als Chance. Frankfurt a. M., Germany: Suhrkamp. 